3. Leonovich I.I. and Pozhakh N.V. Vestnik Belorusskogo Natsionalnogo Tekhnicheskogo Universiteta. 2010 ; № 4 : 8-12 (in Russian).

4. Serdiuk A.M., Polka N.S., Makhniuk V.M., Savina R.V. and Mohylnyi S.M. Hihiiena planuvannia ta zabudovy naselenykh mists na varti hromadskoho zdorovia (do 85-richchia yuvileiu DU "Instytut hromadskoho zdorovia im. O.M. Marzieieva NAMNU" [Hygiene of Planning and Development of Human Settlements on the Watch of Public Health (in Commemoration of the 85-th Anniversary of O.M. Marzieiev Institute for Public Health, NAMSU)]. Kyiv : Medinform ; 2017 : 271 p. (in Ukrainian).

5. Pro yakist atmosfernoho povitria ta chystishe povitria dlia Yevropy : Dyrektyva 2008/50/EU Yevropeiskoho Parlamentu ta Rady Yevropy vid 21.05.2008. [On the Ambient Air Quality and the Cleaner Air for Europe: Directive 2008/50/EU of the European Parliament and of the Council, 21.05.2008] URL :

http://zakon.rada.gov.ua/go/994 _950 (in Ukrainian).

6 . Pro ekolohichnu vidpovidalnist za poperedzhennia ta likvidatsiiu naslidkiv zavdanoi navkolyshnomu seredovyshchu shkody : Dyrektyva 2004/35/EU Yevropeiskoho Parlamentu ta Rady Yevropy vid 21.04.2004 [On the Environmental Responsibility for the Prevention of

Environmental Impact: Directive 2004/35/EU of the European Parliament and the Council, April 21, 2004]. URL : http://zakon. rada.gov.ua/laws/show/994_965

7. Pro otsinku vplyvu na dovkillia : Zakon Ukrainy [On the Environmental Impact

Assessment : Law of Ukraine]. URL : http://zakon3.rada.gov.ua/ aws/show/2059-19 (in Ukrainian).

8. Derzhavni sanitarni pravyla planuvannia ta zabudovy naselenykh mists : DSP 173-96 [State Sanitary Rules for Planning and Building of the Settlements : SSR 173-96]. In : Zbirnyk vazhlyvykh ofitsiinykh materialiv z sanitarnykh i protyepidemichnykh pytan [Collection of the Important Official Materials on Sanitary and Anti-Epidemic Issues]. Kyiv ;

1996 ; 5 (1) : 8-93 (in Ukrainian).

9. Mistobuduvannia. Planuvannia i zabudova miskykh ta silskykh poselen : DBN 360-92** [TownPlanning. Planning and Building of Urban and Rural Settlements : SBN 360-92** ]. Kyiv : Minrehionbud; 1993 : 54 p. (in Ukrainian).

Надійшла до редакції 18.12.2018

\title{
ECOLOGICAL AND HYGIENIC ESTIMATION OF THE CONSTRUCTION MATERIALS FILLED WITH CRUSHED POIYMER WASTE WITH SURFACTANTS DEPOSITED ON THE SURFACE IN AGGRESSIVE ENVIRONMENTS Malyshevska O.S.
}

\section{ЕКОЛОГО-ГГГІЕНЧНА ОЦПНКА ВПЛИВУ НА ДОВКІЛЛЯ БУДІВЕЛЬНИХ МАТЕРІАЛІВ, НАПОВНЕНИХ ПОДРІБНЕНИМИ ПОЛМЕРНИМИ ВІДХОДАМИ, З НАНЕСЕНОЮО НА ПОВЕРХННО ПАР}

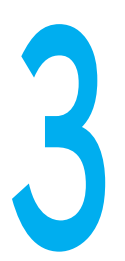

МАЛИШЕВСЬКА О.С.

ДВНЗ “Івано-Франківський національний медичний університет",

м. Івано-Франківськ, Україна

Ключові слова: гігієнічна оцінка, комунальна гігієна, ПАР, переробка полімерів, цементно-піщана суміш. і зростанням обсягів накопичення твердих побутових відходів особливої гостроти набуває проблема їх переробки та утилізації як найбільш об'ємної складової. Відомо, що в Україні щорічно утворюється понад 1 млн. тонн полімерних відходів, і лише близько 18\% з них переробляється, а інша частина потрапляє на полігони для захоронення. Для законодавчого вирішення проблеми поводження $з$ твердими побутовими відходами на розгляді перебуває проект Закону України "Про управління відхо-

\section{ЭКОЛОГО-ГИГИЕНИЧЕСКАЯ ОЦЕНКА ВЛИЯНИЯ НА ОКРУЖАЮЩУЮ} СРЕДУ СТРОИТЕЛЬНЫХ МАТЕРИАЛОВ, НАПОЛНЕННЫХ

ИЗМЕЛЬЧЕННЫМИ ПОЛИМЕРНЫМИ ОТХОДАМИ, С НАНЕСЕННЫМИ НА ИХ ПОВЕРХНОСТЬ ПАВ

Малышевская О.С.

ГВУЗ “Ивано-Франковский национальный медицинский университет г. Ивано-Франковск, Украина

Цель - эколого-гигиеническая оценка строительных материалов, изготовленных из цементно-песчаных композиций, наполненных измельченными полимерными отходами, с нанесенными на поверхность отходов ПАВ в агрессивных средах.

Материалы и методы исследования. Исследования проводились с использованием бытовых и промышленных отходов: полиэтилентетрфталата (ПЭТФ), поливинилхлорида (ПВХ) и смеси полиэтилена и полипропилена (ПЭ + ПП); шлако-портландцемента (ШПЦ) M-400 производства ЧасАО “Ивано-Франковскцемент"; песка мытого речного фракции 0,5-1,0 мм.

Результаты и их обсуждение. Установлено, что наименьшее количество продуктов деструкции выделяется из образцов, наполненных ПЭТФ от 2\% до 10\% от общей массы наполнителя, когда происходит резкое уменьшение потери массы образцов за счет вымывания СаО в условиях углекислотной и расширительной коррозии, а также в дождевой и дистиллированной водах. Ускорение разрушения характерно магнезиальной среде; ПВХ от 2\% до $11 \%$ происходит резкое уменьшение потери массы образцов в условиях всех модельных коррозионных сред, а также в дождевой и дистиллированной водах; смесью ПЭ + ПП от 0,25\% до 2,25\% в условиях всех модельных агрессивных серед, в дождевой и дистиллированной водах. Ни в одном из исследованных образцов не обнаружено превышения концентрации ПАВ выше ПДК для воды питьевого водоснабжения.

Выводы. Гигиеническими исследованиями установлено, что продуктом деструкции образцов цементно-песчаных композицій, наполненных полимерами, является смесь неорганического аморфного осадка, основную массу которого составляют $\mathrm{CaO}, \mathrm{Ca}(\mathrm{OH})_{2}, \mathrm{Ca}\left(\mathrm{HCO}_{3}\right)_{2}$ от $97,83 \%$ до 98,46\% от общей массы осадка, другое - $\mathrm{Mg}(\mathrm{OH})_{2}$, $\mathrm{Al}_{2}(\mathrm{OH})_{3}$. Продукты деструкции являются нетоксичными, нераствори мыми или малорастворимыми простыми неорганическими соединениями, не оказывают негативного влияния на объекты окружающей среды и человека.

Ключевые слова: гигиеническая оценка, коммунальная гигиена, ПАВ, переработка полимеров, цементно-песчаная смесь.

() Малишевська О.С. СТАТTЯ, 2019. 
ECOLOGICAL AND HYGIENIC ESTIMATION OF THE CONSTRUCTION MATERIALS FILLED WITH CRUSHED POLYMER WASTE WITH SURFACTANTS DEPOSITED

ON THE SURFACE IN AGGRESSIVE ENVIRONMENTS Malyshevska O.S.

Ivano-Frankivsk National Medical University, Ukraine

The purpose: ecological and hygienic assessment of building materials made of cement-sand compositions filled with crushed polymer waste with surfactants deposited on the surface in aggressive environments.

Materials and methods of research. The research was conducted using household and industrial waste: polyethylene terephthalate (PETF), polyvinyl chloride (PVC) and polyethylene and polypropylene mixtures $(P E+P P)$; slag-portland cement (MPS) M-400 produced by PJSC "IvanoFrankivsk Cement"; river sand fraction 0,5-1,0 mm. Results and discussion. The results of hygienic research revealed that the lowest amount of degradation products is released from samples filled with: PETF, from $2 \%$ to $10 \%$ of the total weight of the filler, when there is a sharp decrease in the mass loss of samples due to the washing out of
$\mathrm{CaO}$ under conditions of carbon dioxide and extensive corrosion, as well as in the rain and distilled waters. Acceleration of destruction is specific for the magnesian environment; PVC from $2 \%$ to $11 \%$ there is a sharp decrease in the mass loss of samples in conditions of all model corrosion environments, as well as in rain and distilled waters; a mixture of $P E+P P$, from $0.25 \%$ to $2.25 \%$ under conditions of all model aggressive environments and in rain and distilled waters. Exceeding of MACs for drinking water was not detected in samples tested. Conclusions and perspectives. Hygienic studies have found that the product of destruction of samples of cement-sand compositions filled with polymers is a mixture of inorganic amorphous sediment, the main mass of which are: $\mathrm{CaO}, \mathrm{Ca}(\mathrm{OH})_{2}$, $\mathrm{Ca}\left(\mathrm{HNO}_{3}\right)_{2}$, from $97.83 \%$ to $98.46 \%$ of the total mass of sediment, other $-\mathrm{Mg}(\mathrm{OH})_{2}, \mathrm{Al}_{2}(\mathrm{OH})_{3}$. Destruction products are non-toxic insoluble or slightly soluble simple inorganic compounds that have no negative impact on the environment and humans.

Keywords: hygienic assessment, municipal hygiene, surfactants, polymer processing, cement-sand mixture. дами" [1]. У вказаному законопроекті, що імплементує вимоги європейських директив 94/62/ЄС “Про упаковку та відходи від упаковки"; 75/442/ЄС "Про відходи"; 2006/12/ЄС "Про відходи"; 1999/31/ЄС; 2008/98/ЄС "Про захоронення відходів"; 95/157/ЄЕС “Про видалення ПХД та ПХТ"; 91/689/ЄЕС "Про небезпечні відходи"; 99/61/ЄС “Про всеохоплююче запобігання забрудненню та його контроль"; 2008/99/ЄС "Про охорону навколишнього природного середовища та кримінальну відповідальність"; 2000/76/€С "Про спалювання відходів"; 2004/12/ЄС "Про упаковку та відходи від упаковки”; 2010/ 75/€С "Про промислові викиди (комплексне попередження забруднення та контроль над ним)", основним шляхом зменшення кількості накопичення відходів $€$ їх сортування на місці утворення з подальшою переробкою.

Аналіз літературних даних та постановка проблеми. Проблема переробки великої кількості полімерів, присутніх у побутових відходах, на даному етапі не може бути вирішена за допомогою технологій, що ґрунтуються на методах знищення (захоронення, спалювання, фото-, біодеструкції) або розкладання (піроліз, гідроліз, газифікація, крекінг, деполімеризація). Основними стримуючими чинниками впровадження методів переробки виступають їхня дорожнеча на стадії втілення проектів у життя та на стадії експлуатації; матеріало- та ресурсоемкість; необхідність дотримання чітких температурних режимів проведення технологічного процесу; наявність високотоксичних відходів, які потребують подальшої переробки, знищення чи захоронення. Окрім цього, навіть відокремлені та очищені полімерні відходи можна використати як додатки до вихідної сировини для виробництва полімерів лише у невеликих кількостях.

Принципово іншим шляхом $€$ механічна переробка полімерів, що виключає їхні деструктивні зміни, отже і утворення шкідливих речовин та потрапляння їх у довкілля [2]. У процесі механічної переробки полімерів у повітрі робочої зони спостерігається виділення незначної кількості полімерного пилу та мономерів у рази менші за встановлені гранично допустимі концентрації (ГДК).

Композиційні матеріали використовують у техніці та будівництві. Дослідники зосереджуються на вивченні впливу технологічних параметрів формування композиційних матеріалів [3] та дослідженні їхніх фізико-механічних властивостей [4], але недостатню увагу звертають на використання полімерів у складі композиційних матеріалів. Подрібнені на фрагменти полімерні відходи запропоновано використовувати як наповнювачі у цементно-піщаних сумішах [5]. У роботах [4-8] досліджено вплив фрагментів механічно подрібнених полімерних наповнювачів до та після проведення їх механічної активації на фізико-механічні властивості цементно-піщаних композицій, до яких їх додано.

Відомо, що поверхня полімерів $є$ гладкою, тому має низьке зчеплення 3 компонентами цементно-піщаної суміші. На сучасному етапі пропозиції науковців з вирішення даної проблеми обмежуються зміною вигляду полімерних волокон. Волокна виготовляють у формі джгутів, спіралей, хвильок з різноманітними гачечками на їхній поверхні тощо [3, 6, 8]. Усе це сприяє підвищенню фізичного зчеплення з цементним каменем, але не хімічного, яке $є$ найбільш надійним, міцним і довговічним. Якщо створити умови росту кристалів цементної матриці на поверхні полімерного наповнювача, то це вирішить проблему зчеплення полімеру з бетоном. Для покращання зчеплення нами запропоновано нанесення поверхнево-активних речовин (ПАР) на поверхню полімерного наповнювача. Молекули ПАР знижують величину поверхне-

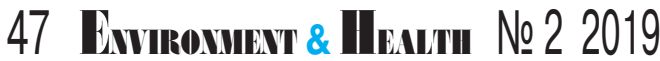


вого натягу, що інтенсифікує процес змочування поверхні. Це викликає збільшення швидкості взаємодії рідкої і твердої фаз у цементно-піщаних сумішах та покращує зчеплення між їхніми компонентами. Застосована нами ПАР - гідрофобна, і на поверхні полімеру утворює скупчення вертикально розташованих молекул, які міцно тримаються на поверхні завдяки хемосорбції. Вкрита поверхня полімеру у результаті нанесення ПАР перетворюється на олеофільну, тобто ПАР стає "клеєм" між поверхнею неорганічних (пісок, цемент, вода) і органічних (полімерні відходи) компонентів сумішей. Проведені нами лабораторні дослідження зміни фізикомеханічних властивостей зразків, виготовлених з цементнопіщаних сумішей, наповнених фрагментами механічно оброблених полімерних відходів, 3 нанесеною на їхню поверхню ПАР та без неї показали покращання стійкості зразків на стиск і на згин. Отримані результати підтвердили правильність і ефективність застосування ПАР для покращання зчеплення полімерів 3 компонентами цементно-піщаної суміші [3].

Однак у цих дослідженнях не проведено гігієнічної оцінки впливу на людину і довкілля будівельних виробів з цементно-піщаних композицій, наповнених подрібненим полімерними відходами, з нанесеними на їхню поверхню ПАР, що стримує практичне впровадження запропонованих матеріалів у виробництво.

Мета. Еколого-гігієнічна оцінка будівельних матеріалів, виготовлених 3 цементнопіщаних композицій, наповнених подрібненими полімерними відходами, з нанесеними на поверхню відходів ПАР в агресивних середовищах.

Матеріали та методи дослідження. Проведено аналіз гігієнічних властивостей матеріалів, виготовлених з цементно-піщаних композицій, наповнених переробленими полімерними відходами, з нанесеними на поверхню відходів ПАР в агресивних середовищах. У ході натурного експерименту 3 використанням інструментально-лабораторних методів дослідження нами встановлено вплив різних агресивних середовищ на хімічну деструкцію цементно-піщаних сумішей, наповнених полімерними відходами, та на основі отриманих даних проведено санітарно-гігієнічну оцінку впливу продуктів деструкції полімерних відходів у складі будівельних композицій на довкілля, зокрема атмосферне повітря, водойми та ґрунт.

Для виготовлення наповнювачів як зразків цементнопіщаних сумішей використали побутові і промислові відходи поліетилентетрфталату (ПЕТФ), полівінілхлориду (ПВХ) та суміші поліетилену і поліпропілену (ПЕ+ПП). Відходи подрібнювали на фрагменти шириною 1,02,5 мм на електричному шредері-смужкорізі довжиною 1015 мм. Смужки нарізали різаком гільйотинного типу, що застосовують для нарізання паперу. Після цього подрібнені полімерні відходи обробляли в активаторі - пристрої для покращання адгезивних властивостей їхньої поверхні відповідно до запатентованої методики (патент на винахід № 110282, UA). У результаті активації одержали волокнистий розшарований шорсткий матеріал у кількості 99,6\% від маси полімерних відходів до активації.

Розчин ПАР (лауретсульфат натрію) готували шляхом попереднього розчинення ПАР у $0,01 \%$ водному розчині $\mathrm{NaCl}$ до концентрації 0,01\% ПАР у розчині, що не перевищувало встановлених гігієнічних вимог до питної води [6]. Для нанесення ПАР на поверхню фрагментів перероблених полімерних відходів розробили пристрій 3 замкнутою системою подачі повітря. Пристрій забезпечував нанесення розчину ПАР із пароподібної фази на поверхню цих фрагментів 3 одночасним їх перемішуванням. Оброблені таким чином фрагменти полімерних відходів висушували у цьому ж пристрої у висхідному потоці холодного повітря (без присутності ПАР). Висушену сировину вивантажували із пристрою.

Для виготовлення зразків за допомогою лабораторних вагів відважували необхідну кількість: шлако-портландцементу (ШПЦ) М-400 виробництва Івано-Франківського цемент- ного заводу; піску митого річкового фракції 0,5-1,0 мм; подрібнених на фрагменти активованих полімерних відходів, оброблених ПАР.

Після цього підготовані полімерні відходи додавали до сухої суміші з піску та цементу за методикою стандарту EN 206-1 [7]. Співвідношення компонентів досліджуваних піщано-цементних сумішей: пісок цемент - вода $(3: 1: 0,4)$ - перероблений полімерний наповнювач (ПЕТФ, ПЕ+ПП, ПВХ) 0,25-26,5\% від маси піску у суміші (з кроком від 0,25\%). Контрольна суміш містила цемент (500 г), пісок (1500 г), воду (250 мл). Досліджуван суміші перемішували змішувачем і, не припиняючи процесу, до сумішей додавали воду і змішували ще протягом 1 хвилини. Після цього суміші залишали на 15 хвилин і знову перемішували з метою виключення передчасного схоплення у сумішах. Потім суміші пошарово укладали у змащені мастилом металеві форми ущільнювали на вібраційному столі. Зразки витримували у формах $24( \pm 2)$ години, після цього розформовували. Розформовані зразки 7 діб витримували у вологому середовищі та 21 добу - на повітрі за нормальних умов. Контрольними зразками були цементно-піщані суміші без полімерних наповнювачів.

Розрахунки, необхідні для оцінки втрати маси зразків у різних типах агресивних середовищ, проведено згідно зі СНіП 2.03.11-85 [8]. Склад продуктів корозії цементно-піщаної суміші визначали за ДСТУ 4079-2001 [9] та методикою [10]. Визначення кількості ПАР, що вимилась із досліджуваних зразків, провели згідно з методикою ДСТУ ISO 7875-1:2012 [11], яка ґрунтується на спектрофотометричному визначенні вмісту ПАР у воді. Ця методика забезпечує отримання результатів вимірювань 3 імовірністю у межах 0,95.

Еколого-гігієнічну оцінку виготовлених зразків та двох порівняльних провели за методиками [8-11] у модельних водних агресивних середовищах: а) розширювальному $10 \%$ розчин $\mathrm{Na}_{2} \mathrm{SO}_{4}$; б) карбонатному - $10 \%$ розчин $\mathrm{H}_{2} \mathrm{CO}_{3}$; в) магнезіальному - 10\% роз- 
чин $\mathrm{MgCl}_{2}$; г) дистильованій воді; д) дощовій воді.

Досліджувані зразки занурювали на 28 діб в ємності 3 модельними розчинами. Визначали та оцінювали втрату іонів $\mathrm{Ca}^{2+}$ із зразків кожні 3 доби шляхом титрування розчину, в якому вони перебували. Після 28 діб зразки промивали дистильованою водою і зважували. Таким чином визначали втрату маси зразків.

Для дослідження стійкості зразків до впливу кислотної корозії використовували метод титрування, заснований на законі еквівалентів. Для цього досліджувані зразки вміщували в ємності 2500 мл, заливали 2000 мл модельних розчинів і витримували за нормальних умов.

Кількість $\mathrm{CaO}$, що перейшла із цементного каменя зразка у розчин, визначали за зміною концентрації соляної кислоти, яку розраховували за формулою [8]:

$\mathrm{a}=(\Delta \mathrm{V} \cdot 0.0028 \cdot[250-5(\mathrm{n}-1) / 5]) / \mathrm{F}$ де а - кількість $\mathrm{CaO}$, що пе-

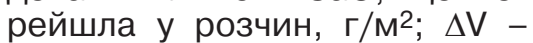
об'єм 0,1 Н розчину КОН, витраченого на титрування розчину, мл; 0,0028 - кількість $\mathrm{CaO}$, еквівалентну 1 мл 0,I Н розчину $\mathrm{KOH}$; n - тривалість вилуговування, доба; F - площа поверхні зразка, м².

Окрім цього паралельно 3 методом титрування для визначення корозійної стійкості зразків цементно-піщаних сумішей у різних агресивних середовищах використовували гравіметричний метод дослідження. Даний метод оснований на вимірюванні на електронних вагах втрати маси зразка до і після перебування в агресивному середовищі залежно від часу перебування у ньому.

Для визначення кількості ПАР, що вимилася модельним розчином із досліджуваних зразків, використали фотоелектроколориметр КФК-2. Екстракцію досліджуваних модельних розчинів з ПАР проводили з використанням хімічних реактивів: дигідрофосфату калію, метиленового синього, фенолфталеїну, хлороформу.

Результати досліджень та їх обговорення. Графічні залежності впливу концентрації полімерних наповнювачів 3 нанесеними ПАР на поверхню та без на корозійну втрату маси зразків у різних агресивних середовищах та їх порівняння 3 ненаповненими полімерними відходами зразками 3 ПАР та без представлено на рисунках 1-3.

З рисунка 1 видно, що під час заміни піску на ПЕТФ-наповнювач $з$ нанесеним ПАР на його поверхню у цементних композиціях у кількості від 2\% до 10\% від загальної маси піску відбувається різке зменшення втрати маси зразків за рахунок вимивання $\mathrm{CaO}$ в умовах вуглекислотної і розширювальної корозій, а також у дощовій і дистильованій водах. Зі збільшенням кількості полімерного наповнювача зменшення маси зразків незначно підвищується.

Корозія цементно-піщаного каменя у розчинах солей супроводжується за відповідних температурно-вологих умов переходом ряду солей із безводної або маловодної своєї форми $\left(\mathrm{Na}_{2} \mathrm{SO}_{4}, \mathrm{MgSO}_{4} \cdot \mathrm{H}_{2} \mathrm{O}\right)$ у порах каменя до висоководних форм кристалогідратів $\left(\mathrm{Na}_{2} \mathrm{SO}_{4} \cdot 10 \mathrm{H}_{2} \mathrm{O}, \mathrm{MgSO}_{4} \cdot 7 \mathrm{H}_{2} \mathrm{O}\right)$ [12].

Схематично розширювальну корозію цементно-піщаної суміші ілюструє реакція:

$\mathrm{Na}_{2} \mathrm{SO}_{4}+\mathrm{H}_{2} \mathrm{O}=\mathrm{Na}_{2} \mathrm{SO}_{4} \cdot 10 \mathrm{H}_{2} \mathrm{O}$.

Іншим видом корозії є карбонатна корозія, що відбувається за схемою:

$\mathrm{Ca}(\mathrm{OH})_{2}+\mathrm{H}_{2} \mathrm{CO}_{3}=\mathrm{CaCO}_{3}+2 \mathrm{H}_{2} \mathrm{O}$;
$\mathrm{CaCO}_{3}+\mathrm{H}_{2} \mathrm{CO}_{3}=\mathrm{Ca}\left(\mathrm{HCO}_{3}\right)_{2}$.

Посилене розчинення $\mathrm{Ca}(\mathrm{OH})_{2}$ відбувається при обмінній реакції 3 солями катіонів, що утворюють важкорозчинні гідроксиди. До таких процесів належить магнезійна корозія [12].

Схематично вона відбувається за реакцією:

$\mathrm{Ca}(\mathrm{OH})_{2}+\mathrm{MgCl}_{2}=\mathrm{Mg}(\mathrm{OH})_{2}+$ $\mathrm{CaCl}_{2}$;

$2 \mathrm{CaO} \cdot \mathrm{SiO}_{2} \cdot 2 \mathrm{H}_{2} \mathrm{O}=2 \mathrm{Ca}(\mathrm{OH})_{2}+$ $\mathrm{SiO}_{2} \cdot 2 \mathrm{H}_{2} \mathrm{O}$.

Розчин, що перебуває у рівновазі з $\mathrm{Mg}(\mathrm{OH})_{2}$, має $\mathrm{pH}=10,5$. Це нижче значень, необхідних для стійкого існування майже усіх сполук, що складають цементний камінь. Сполуки розкладаються з виділенням $\mathrm{Ca}(\mathrm{OH})_{2}$, який знову вступає у реакцію з $\mathrm{MgCl}_{2}$. Так продовжується доти, доки розкладуться сполуки цементного каменя [12].

Дослідженнями встановлено, що втрата маси зразків від початкової маси склала за 28 діб

а) без наповнювача - у 10\% розчині $\mathrm{H}_{2} \mathrm{CO}_{3}-5,4 \%$, у $10 \%$ розчині $\mathrm{MgCl}_{2}-2,7 \%$; у $10 \%$ розчині $\mathrm{Na}_{2} \mathrm{SO}_{4}-7,53 \%$, у дистильованій воді - 0,32\%; у дощовій воді - 1,94\%;

б) без наповнювача з додаванням 0,1 мл 0,01\% розчину ПАР у воду для виготовлення у $10 \%$ розчині $\mathrm{H}_{2} \mathrm{CO}_{3}-4,23 \%$; у $10 \%$ розчині $\mathrm{MgCl}_{2}-2,67 \%$; у

Рисунок 1

Корозійна втрата маси зразків залежно від концентрації ПЕТФ-наповнювача з нанесеними ПАР на поверхню та без них у різних агресивних середовищах протягом 28 діб

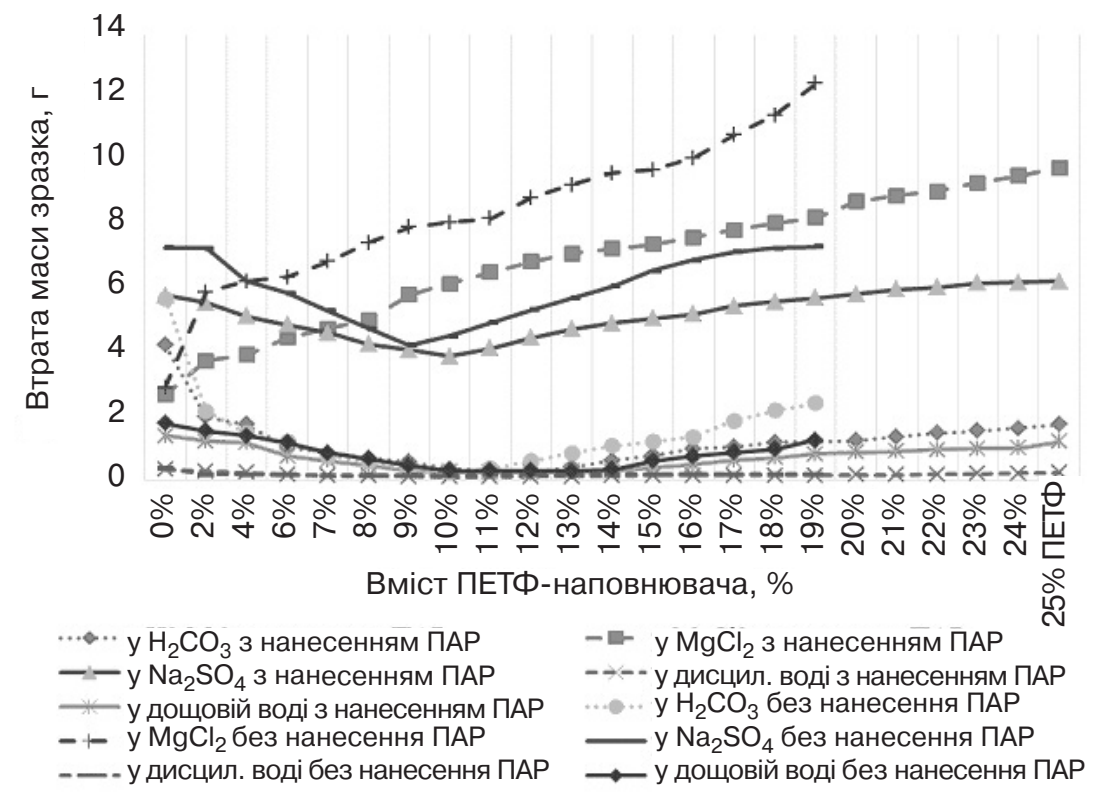


$10 \%$ розчині $\mathrm{Na}_{2} \mathrm{SO}_{4}-5,8 \%$, у дистильованій воді - 0,31\%; у дощовій воді - 1,37\%.

Однак зменшення маси досліджуваних зразків $€$ у рази меншим за зменшення маси контрольних зразків в аналогічних умовах. Зазначимо, що нанесення ПАР на поверхню полімерного наповнювача дало можливість зменшити втрату маси наповнених полімерами зразків в умовах магнезіальної корозії на 34,4\% порівняно зі зразками, наповненими полімерами, на поверхню яких

Корозійна втрата маси зразків залежно від концентрації ПВХ-наповнювача з нанесеними ПАР на поверхню та без у різних агресивних середовищах протягом 28 діб

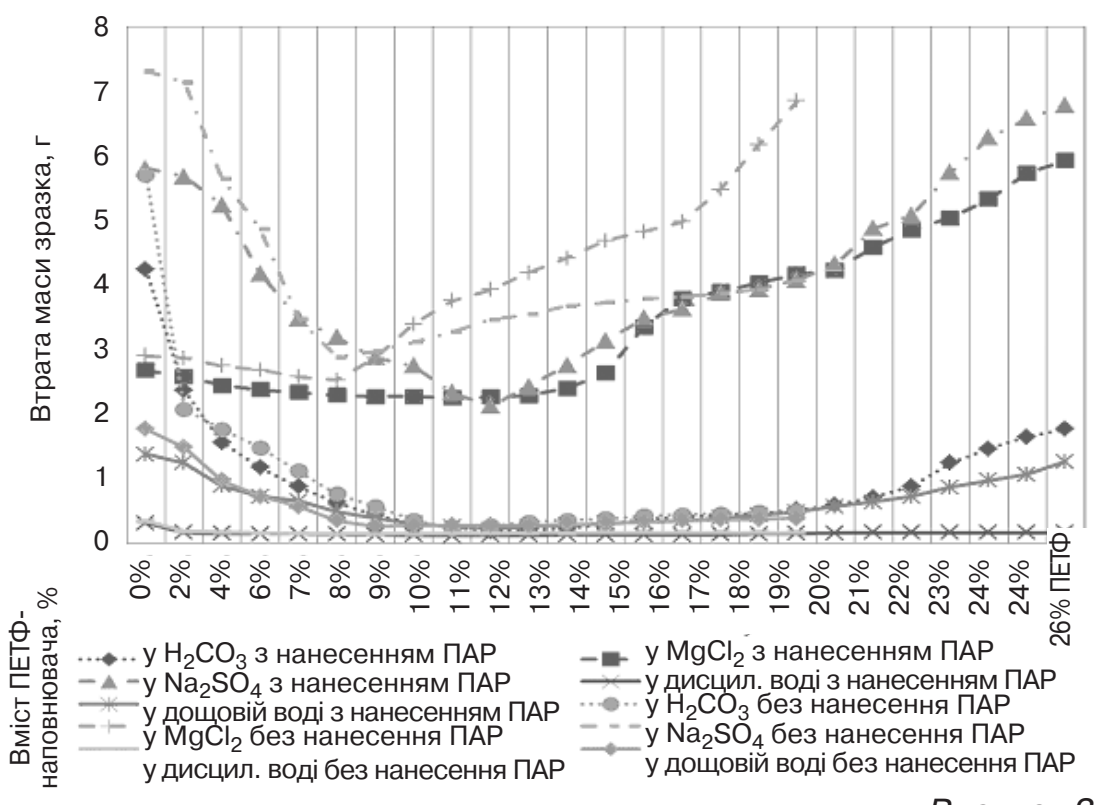

Корозійна втрата маси зразків залежно від концентрації ПЕ+ПП-наповнювача 3 нанесеними ПАР на поверхню та без у різних агресивних середовищах протягом 28 діб

8

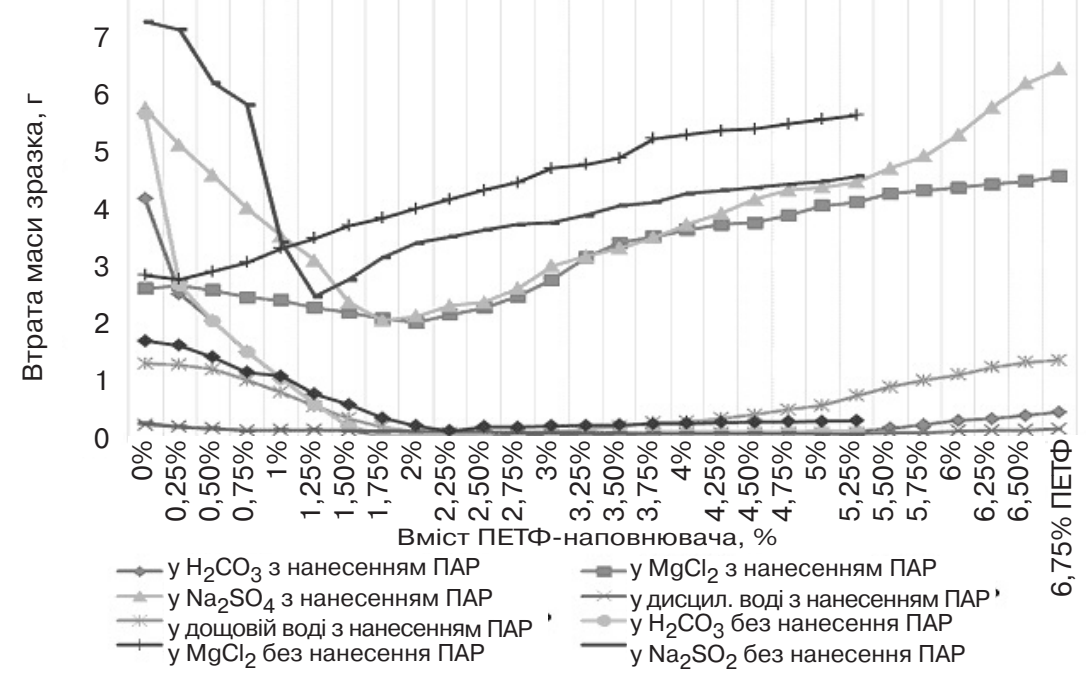

дах. Однак додавання полімерного наповнювача більше 14\% призводить до пришвидшення зменшення маси зразків у середовищі $\mathrm{MgCl}_{2}$ порівняно зі зразками без ПВХнаповнювача.

Аналіз графічних залежностей, представлених на рисунку 3, показав, що додавання суміші ПЕ+ПП-наповнювача, на поверхню якого нанесено ПАР, у цементні композиції у кількості до 2,5\% від загальної маси наповнювача сприяє збільшенню стійкості зразків в усіх модельних середовищах. Нанесення на поверхню полімерів даного типу ПАР підвищило стійкість досліджуваних зразків у різних типах агресивних середовищ від 9\% до $23,7 \%$ порівняно зі зразками, наповненими полімерами, поверхню яких не було вкрито ПАР.

Встановлено, що продуктом деструкції зразків цементнопіщаних композицій, наповнених полімерами, Є неорганічний аморфний осад: (CaO + $\left.\mathrm{Ca}(\mathrm{OH})_{2}+\mathrm{Ca}\left(\mathrm{HCO}_{3}\right)_{2}\right)$ від 97,83\% до 98,46\%; $\left(\mathrm{Mg}(\mathrm{OH})_{2}+\right.$ $\left.\mathrm{Al}_{2}(\mathrm{OH})_{3}\right) \leq 2,2 \%$ від загальної маси осаду.

Продукти деструкції $€$ гігієнічно безпечними, нетоксичними, нерозчинними або малорозчинними простими неорганічними сполуками згідно з [6], що не справляють значного шкідливого впливу на об'єкти довкілля та людину. Найкращі показники стійкості в агресивних середовищах мали цементні композиції, наповнені полімерними відходами, на поверхню яких було нанесено ПАР - лауретсульфат натрію, який не включений до переліку заборонених до використання речовин у косметичній Директиві Європи 76/768/EEC [13]

Як видно 3 рисунка 4, у жодному дослідженому зразку не виявлено концентрації ПАР вище ГДК, яке для питного водопостачання становить 0,5 мг/дм ${ }^{3}[6]$.

Порівняння з санітарно-гігієнічними нормами для води, що призначена для питного водозабезпечення, зумовлене перспективою використання розроблених цементно-піщаних сумішей для спорудження резервуарів питної води та конструкцій, які експлуатува- 
тимуться у поверхневих водотоках, вода з яких може бути джерелом питного водопостачання населення. Максимальна концентрація ПАР, що перейшла у водний розчин, стОм ПЕТФ 26,25\% у кількості

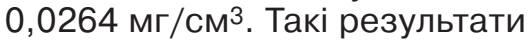
було отримано нанесенням ПАР на поверхню полімерного наповнювача майже у вигляді наношару, що стало можливим завдяки створеному пристрою та розробленою авторами технології нанесення шару ПАР.

Результати дослідження показали, що цементні композиції наповнені полімерними відходами, на поверхню яких нанесено ПАР, мають високу корозійну стійкість в умовах дії різних агресивних хімічних середовищ та $€$ гігієнічно і екологічно безпечними. Тому розмендувати для спорудження та облаштування ємностей для зберігання агресивних хімічних речовин, спорудження екранів, дамб, уловлювачів, облаштування каналізаційних мереж, нанесення в якості дорожніх покриттів в умовах дії агресивних хімічних речовин на хімічних підприємствах, нафтобазах і автозаправних станціях тощо.

Висновки та перспективи подальших досліджень. Аналіз отриманих результатів еколого-гігієнічної оцінки зміни хімічної стійкості цементних композицій, наповнених обробленими ПАР полімерними відходами, у різних хімічно-агресивних середовищах показав, що для досліджених зразків значно покращилися показники хімічної стійкості у модельних агресивних середовищах порівняно зі зразками, наповненими полімерними відходами, на поверхню яких ПАР нанесено не було.

На підставі проведених гігієнічних досліджень зразків цементно-піщаних сумішей, наповнених різними видами полімерних відходів, на поверхню яких нанесено ПАР, встановлено:

$\square$ неорганічний аморфний осад $\mathrm{CaO}+\mathrm{Ca}(\mathrm{OH})_{2}+\mathrm{Ca}\left(\mathrm{HCO}_{3}\right)_{2}$ $+\mathrm{Mg}(\mathrm{OH})_{2}+\mathrm{Al}_{2}(\mathrm{OH})_{3}$, що є продуктом корозійного руйнування зразків цементно-піщаних комбула виявлена у зразку з вміроблені матеріали можна реко- позицій, наповнених полімерами, є малотоксичним, складений мало- та нерозчинними простими неорганічними сполуками, які практично не впливають на компоненти довкілля та людину;

口 найбільш стійкими у модельних агресивних середовищах є цементно-піщані композиції з вмістом ПЕТФ-наповнювача, на поверхню якого нанесено ПАР, у кількості $10 \%$ від загальної маси наповнювача. Нанесення ПАР на поверхню полімерного наповнювача дало можливість зменшити втрату маси зразків в агресивних середовищах до $34,4 \%$ порівняно зі зразками, наповненими полімерами, на поверхню яких не нанесено ПАР. Однак нанесення ПАР не збільшило стійкості зразків в умовах магнезіальної корозії порівняно зі зразками без полімерного наповнювача;

для зразків цементнопіщаних композицій 3 ПВХнаповнювачем, на поверхню якого нанесено ПАР, найкращі результати стійкості у модельних середовищах досягнуто за вмісту наповнювача у зразках у кількості 11\%. Порівняно зі зразками цементно-піщаних сумішей з наповнювачем ПВХ, на поверхню якого не нанесено ПАР, додаванням ПАР зменшено втрату маси зразків в агресивних середовищах;

口 зразки цементно-піщаних композицій, наповнені сумішшю ПЕ+ПП наповнювача у кількості до 2,5\% від загальної маси наповнювача, на поверх-

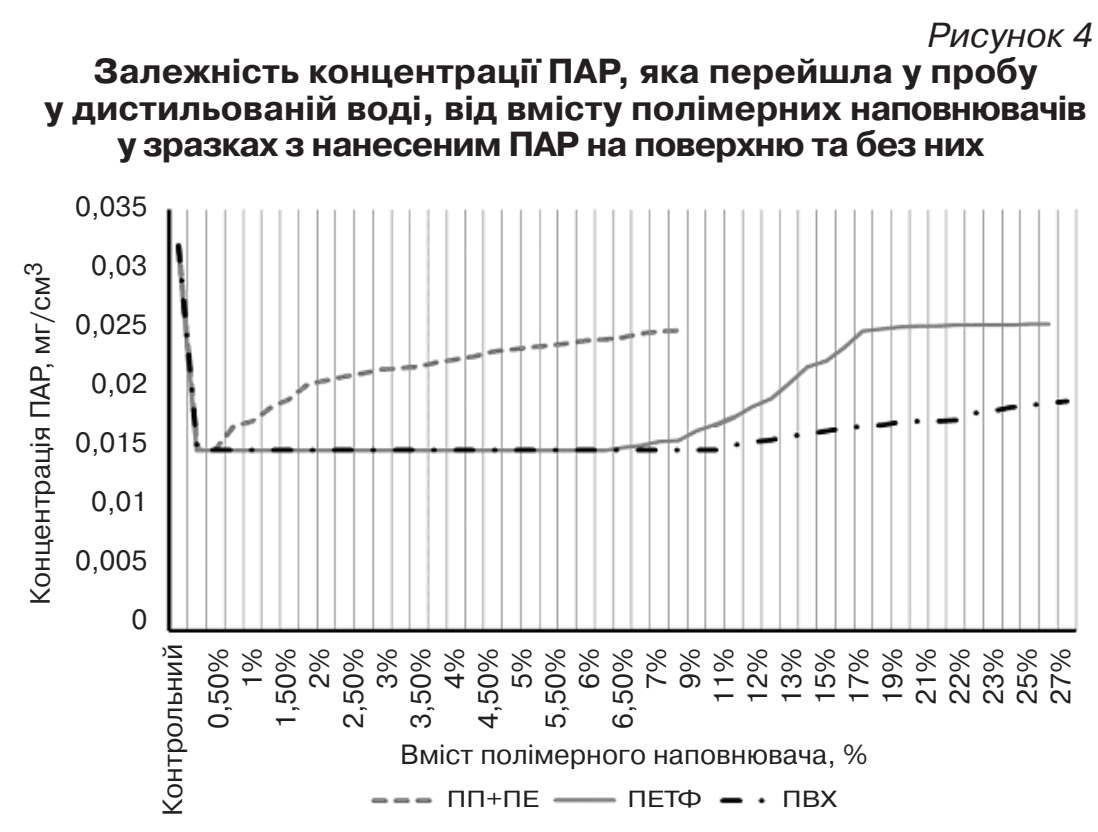
зали збільшення корозійної стійкості зразків в усіх модельних агресивних середовищах від 9\% до 23,7\% порівняно зі зразками, поверхню яких не було вкрито ПАР;

$\square$ у жодному дослідженому зразку не виявлено перевищення концентрації ПАР, яка нанесена на поверхню полімерного наповнювача, вище встановлених ГДК для води питного постачання;

$\square$ зменшення маси продуктів деструкції цементно-піщаних сумішей з полімерними наповнювачами, обробленими ПАР, дозволяє не тільки вирішувати проблему забрудненості навколишнього середовища побутовими відходами, але й не несе загрози екології довкілля та здоров'ю людини.

Напрямком подальших наукових досліджень буде гігієнічна оцінка впливу концентрації полімерних наповнювачів, оброблених ПАР, у зразках цементно-піщаних композицій на концентрацію ПАР, яка перейшла у розчини модельних агресивних середовищ.

ЛІТЕРАТУРА

1. Проект Закону України "Про управління відходами". URL : https://menr.gov.ua/ news/32869.html

2. Малишевська О.С. Еколого-гігієнічна оцінка технології механічної переробки полімерних побутових відходів. Вісник проблем біології $і$ медицини. 2018. Вип. 2 (144). C. $122-126$. doi $10.29254 / 2077$ 4214-2018-2-144-122-126.

Рисунок 4 ню якого нанесено ПАР, пока-

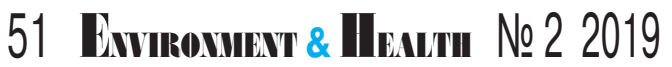


3. Роп'як Л.Я., Шуляр І.О., Богаченко О.М. Вплив технологічних параметрів процесу відцентрового армування на показники якості деталей. Східно-європейський журнал передових технологій. 2016. Vol. 1 (5). P. 53-62. doi

10.15587/1729-

4061.2016 .59850$.

4. Raju Sharma R., Bansal P.P. Use of different forms of waste plastic in concrete - A review. Journal of Cleaner Production. 2016. Vol. 112. P. 473-482. URL : https://doi.org/10.1016/j.jclepr 0.2015 .08 .042 .

5. Zander N.E., Gillan M., Sweetser D. Composite Fibers from Recycled Plastics Using Melt Centrifugal Spinning. Materials (Basel). 2017. Vol. 10 (9). URL : https://doi.org/10.3390/ma100 91044.

6. Про затвердження Державних санітарних норм і правил "Гігієнічні вимоги до питної води, призначеної для споживання людиною : ДСанПіН 2.2.4-171-10" : Наказ МО3 України № 400 від 12.05.2010. URL : https://zakon.rada.gov.ua/laws/ show/z0452-10

7. EN 206-1 Concrete - Part 1: Specification, performance, production and conformity. URL : https://asma.com.ua/files/gosts /en 2061 beton chast_1_obsc hie_tehnicheskie_trebovaniya_p roizvodstvo i kontrol kachestva.pdf.

8. СНиП 2.03.11-85. Защита строительных конструкций от коррозии. Москва : Госстрой CCCP, 1996.56 c. URL :

http://www.gostrf.com/normadata/1/4294854/4294854818.p $d f$.

9. ДСТУ 4079-2001.

Визначення загального вмісту хлоридів. Титрування нітратом срібла з застосуванням хромату як індикатора (метод Мора). Введ. 28.12.2001. Київ :

Держстандарт України, 2002. 6 с.

10. Горшков В.С., Тимашев В.В., Савельев В.Г. Методы физико-химического анализа вяжущих веществ. М. : Высшая школа, 1981. 334 с.

11. ДСТУ ISO 7875-1:2012. Якість води. Визначення поверхнево-активних речовин. Частина 1. Метод визначення вмісту аніонних поверхнево- активних речовин вимірюванням індексу метиленового блакитного (МБАР). Київ :

Мінекономрозвитку

України, 2013.

12. Дворкин Л.И., Дворкин О.Л. Основы бетоноведения. Санк-Петербург : ООО "Строй-бетон", 2006. $691 \mathrm{c}$.

13. Council Directive $76 / 768 /$ EEC of 27 July 1976 on the approximation of the laws of the Member States relating to cosmetic products. URL : https://eurlex.europa.eu/LexUriServ/LexUr iServ.do? uri=CONSLEG: 1976 LO 768:20100301:en:PDF.

\section{REFERENCES}

1. Proekt Zakonu Ukrainy "Pro upravlinnia vidkhodamy" [The Project of the Law of Ukraine "On Waste Handling"]. URL : https://menr.gov.ua/news/3286 9. html (in Ukrainian).

2. Malyshevska O.S. Visnyk problem biolohii i medytsyny. 2018 ; 2 (144) : 122-126. doi 10.29254/2077-4214-2018-2144-122-126

(in Ukrainian).

3. Ropiak L., Schuliar I. and Bohachenko O. EasternEuropean Journal of Enterprise Technologies. 2016 ; 1 (5) : 5362. doi 10.15587/17294061.2016 .59850 (in Ukrainian).

4. Raju Sharma R. and

Bansal P.P. Journal of

Cleaner Production. 2016 ;

112 : 473-482. URL :

https://doi.org/10.1016/j.jclepr o.2015.08.042.

5. Zander N.E., Gillan M. and Sweetser D. Materials (Basel) 2017 ; 10 (9). URL :

https://doi.org/10.3390/ma100 91044

6. Pro zatverdzhennia

Derzhavnykh sanitarnykh norm i pravyl "Hihiienichni vymohy do pytnoi vody, pryznachenoi dlia spozhyvannia liudynoiu :

DSanPiN 2.2.4-171-10" : nakaz

MOZ Ukrainy № 400 vid

12.05.2010 [On the Approval of the State Sanitary Norms and Rules "Hygienic Requirements to

Drinking Water for Human

Consumption : SSanRN 2.2.4-

171-10": Order of the MPH of

Ukraine № 400, 12.05.2010].

URL : https://zakon.rada.

gov.ua/laws/show/z0452-10

(in Ukrainian).

7. EN 206-1 Concrete - Part 1: Specification, performance, production and conformity. URL: https://asma.com.ua/files/gosts /en_206_1_beton_chast_1_obsc hie_tehnicheskie_trebovaniya_p roizvodstvo_i_kontrol_kachestva.pdf.

8. SNiP 2.03.11-85. Zashchita stroiteknykh konstruktsiy ot korrozii [SNR 2.03.11-85.

Protection of Building Constructions from Corrosion]. Moscow : Gosstroy SSSR; 1996 : 56 p. URL : http://www.gostrf. com/normada-

ta/1/4294854/4294854818.pdf (in Russian).

9. DSTU 4079-2001.

Vyznachennia zahalnoho vmistu khlorydiv. Tytruvannia nitratom sribla iz zastosuvanniam khromatu yak indykatora [SSU 4079-2001.

Determination of Total Content of Chlorides. Titration with Silver Nitrate with the Use of Chromate as an Indicator (More's Method)]. Kyiv : Derzhstandart Ukrainy ; 2002 : 6 p. (in Ukrainian).

10. Gorshkov V.S.

Timashev V.V. and Savelev V.G. Metody fiziko-khimicheskogo analiza viazhushchikh veshchestv [Methods of PhysicoChemical Analysis for Binding Agents]. Moscow : Vysshaya shkola ; 1981: $334 \mathrm{p}$.

(in Russian)

11. DSTU ISO 7875-1:2012.

Yakist vody. Vyznachennia poverkhnevo-aktyvnykh rechovyn. Ch. 1. Metod vyznachennia vmistu anionnykh poverkhnevo-aktyvnykh rechovyn vymiriuvanniam indeksu metylenovoho blakytnoho (MBAR) [Water Quality Determination of Surfactants Part 1: Determination of Anionic Surfactants by Measurement of the Methylene Blue Index (MBAS)]. Kyiv : MinekonomrozvytkuUkrainy; 2013 (in Ukrainian).

12. Dvorkin L.I. and Dvorkin O.L. Osnovy betonovedeniya [Fundamentals of Concrete Science]. Sankt-Peterburg ; 2006 : $691 \mathrm{p}$.

(in Russian).

13. Council Directive 76/768/EEC of 27 July 1976 on the Approximation of the Laws of the Member States Relating to Cosmetic Products. URL :

https://eur-lex.europa.eu/ LexUriServ/LexUriServ.do?uri= CONSLEG:1976L0768:2010030 1:en:PDF.

Надійшла до редакції 01.03.2019 